Can There Be Conversion Without Cultural Change?

To Appear in the journal Mission Studies 


\section{Can There Be Conversion Without Cultural Change?}

This article takes a sociocultural anthropological approach to conversion. It asks not about the causes of conversion, but about the kinds of cultural changes conversion produces and the mechanisms by which it brings about such changes. Drawing on the author's research among a recently converted group in Papua New Guinea and on other work produced by scholars working in the anthropology of Christianity, the article argues that Christianity is a culture of secondarity, designed to come after another culture that previously guided its converts. Moreover, Christian converts tend to engage their prior cultures not by completely rejecting them, but by evaluating their components critically in relation to new Christian values. This produces a duplex cultural formation that regularly fosters critical reflection and ongoing cultural change. This model of change is briefly distinguished from more common models of syncretism, suggesting a new understanding of the relationship between conversion and cultural change.

(Keywords: Conversion, Culture, Cultural Change, Anthropology of Christianity, Values, Christianity and Culture, Secondarity, Duplex Cultural Formations) 
One of the most fundamental justifications for doing anthropology is the claim that people come to see themselves in new terms once they have seriously encountered ways of life other than their own. Put otherwise, other ways of life can act as mirrors that reflect us back to ourselves from angles different from those we are used to. This holds for scholarly ways of life as well as it does for others. In that spirit, the following discussion of conversion is written very much from the perspective of sociocultural anthropology, my own field, rather than that Mission Studies. My hope in what follows is that by demonstrating how anthropologists think about topics like conversion and cultural change that I know are important for Mission Studies, I might offer up a mirror of this sort - allowing readers to explore some their key concerns from a disciplinary vantage point that to some at least will be a little bit unfamiliar.

Remarks made in an anthropological voice today might have some relevance for discussions in Mission Studies that they would not have had in the past because anthropology has changed dramatically in the last twenty years or so. I doubt I need to recall here that for a long time anthropologists were largely averse to studying Christian populations, and this aversion was even stronger when it came to studying people who were in the midst of processes of conversion or who had recently converted, rather than those that had been Christian for a long time. Yet over the last two decades, many anthropologists have set this aversion aside and have come to study Christian groups, including recently Christianized ones. It is fair to say that at present what is often called the Anthropology of Christianity is one of the most flourishing corners of the discipline. A very useful bibliography blog named AnthroCyBib lists 900 books and articles 
published in this field in just in the last five years. The story of why the anthropological study of Christianity took off when it did, and of why it was so late in developing, has been told a number of times before and I am not going to repeat it here (Cannell 2006, Author 2003, 2014). I have, however, been involved with the development of this field form the beginning and I will draw both on my own research and on some of the literature this boom has produced in what follows. My wager is that this intense recent anthropological interest in Christianity means that we have a reached a point where a fundamentally anthropological discussion of conversion might provide just the kind of useful mirror for Mission Studies that I mentioned above.

With that background in place, let me ask the anthropological question that is going to concern me today: can someone or a group of people convert without changing their culture? Put in most straightforward terms, I am going to argue that the answer to this question is "no," conversion per force requires some kind of cultural change. But the real import of this claim will only come out when I render my argument a bit more complex by specifying to some extent, at least for Christian conversion, what kind of cultural change this is likely to be. To make this argument, I am going to need to consider at great length than you might have expected me to the question of how we should think theoretically about the notion of culture itself, as a necessary prelude to talking about what it means for a culture to change. These theoretical issues will occupy the middle section of this article. But it is also that case that my own primary fieldwork lead me quite directly to the questions I am addressing here concerning the nature of culture, conversion and cultural change. Explaining why this is so provides a good way into the main arguments I will be making. 


\section{Conversion and Cultural Change in a Papua New Guinea Society}

In the early 1990s, I carried out over two years of fieldwork among the Urapmin, a discrete language group of roughly 400 speakers in the far Western Highlands of Papua New Guinea. The Urapmin were first colonized only in the late 1940s. Shortly thereafter, by the early 1950s, the Australian Baptist Missionary society sent missionaries to the colonial government center of the region, an emerging rural town known as Telefomin. In this mountainous region, the Urapmin community sits a tough six or seven hour walk from Telefomin and so the Baptist missionaries rarely visited them. In the 1960s, they did send a Telefomin man whom they had trained to evangelize the Urapmin, but he quickly found himself involved with a young local woman and was expelled. From then on, the Urapmin came to engage Christianity primarily on their own initiative.

By the late 1960s, the Urapmin were well aware that many of their neighbors who had missionaries living with them had begun to take up Christianity. These were groups with whom the Urapmin were part of a complex traditional regional ritual system that was coming under threat of collapse as many of its members joined the new faith. In response, some Urapmin adults decided to send their children to learn about Christianity at schools the missionaries had set up in Telefomin. Most of these young people converted and brought their understanding of Christianity home to Urapmin, teaching others in the community a lot about the Christian faith and also, quite remarkably, training many to read the New Testament in Tok Pisin, the primary lingua franca of Papua New Guinea. Yet despite their avid interest in the teaching of these young Christians, few Urapmin who had not been to the mission school converted. By the mid- 
1970s, then, Urapmin was a community in which many people knew a good deal about Christianity, even if few practiced it and traditional religion remained at the center of community life. ${ }^{1}$

The religious situation in Urapmin changed radically in 1977. That year, a charismatic Christian revival that had started in New Zealand made its way to Papua New Guinea and was rapidly carried from place to place by local people. Some young Urapmin men studying at a locally run bush Bible College in their region encountered the revival there and rushed home to pray that the Holy Spirit would come to Urapmin. Soon many people began to have experiences of being, as they recount it, "kicked" by the Spirit. They shook violently, felt hot and became deeply convinced of their own sinfulness. Some were given gifts of preaching, healing, reading the Bible with new understanding, and seeing the sins of others. Within a year, everyone in the community above the age of about 13 had either had such charismatic experiences or watched as their relatives had them. This convinced people, again as they put it, the "God truly exists." As Urapmin people explain their conversions, they were caused solely by the power of God and the Holy Spirit. They talk about the revival as the time "when Holy Spirit came and got us.” By the end of 1977, everyone in the community was Christian.

For my purposes today, what it is important to stress is that this period of rapid group conversion quickly led to very dramatic cultural changes. Once the revival was under way, some of the younger people who had previously converted while studying at the mission school led a move to physically dismantle traditional Urapmin religion. Men's cult houses where older men formerly sacrificed game to the ancestors in order to prosper people's crops and ensure community health were taken down and the ancestral 
bones they harbored were "thrown out" in the bush. In their place, first one and then two churches were built, and people began to attend daily services, often morning and night during the early years of the revival, where they would pray, sing hymns, and hear Bible readings and sermons from their mission-trained local pastors.

People also disposed of magical stones and seeds and other materials used in everyday rites by burning them or tossing them down the otherwise unused pit latrines the government had made them dig. In place of the rites in which these magical materials once figured, people began to pray for God's support in the course of all their daily activities.

Equally strikingly, people set aside an elaborate system of taboos put in place by the Urapmin creator spirit Afek and by nature spirits who the Urapmin formerly reckoned owned all the natural resources they used. Everyone began to eat all kinds of food and with all kinds of people, hunters began to hunt in formerly taboo parts of the forest, and gardeners started to garden on formerly taboo ground. God, the Urapmin now argued, made all the things of the earth and he wanted everyone to use them. To disregard his wishes by observing taboos came to be defined as a sin. Now that they are Christians, the Urapmin say using terms that have been borrowed from English, it is "free time" - people do not have to, and indeed should not, follow any of the traditional prohibitions that used to regulate many aspects of their everyday lives.

Clearly, Christian conversion very quickly and radically began to transform Urapmin culture. But just to make sure this point is not missed, let me mention one other quite dramatic change that occurred in the course of the revival. The traditional Urapmin system of taboos heavily restricted various forms of contact between men and women. 
Men and women, for example, had to walk on separate paths through the community and the forest. They also ate separately. And women and children slept in single-family "women's houses" set in a horseshoe pattern around each village, while men slept in the men's cult houses in the center. Urapmin say all of the gender-contact taboos were abandoned during the revival. And certainly by the time I arrived for my fieldwork at the very beginning of 1990 s, 13 or 14 years after the start of the revival, there was no sign of separate paths, men and women ate together, the men's cult houses were gone, and men and women all slept in the women's houses. Along with religious ideas and ritual life, gender relations emerged profoundly transformed by Urapmin conversion.

In the wake of such cultural changes, during the period of my fieldwork among them it is fair to say that Urapmin was a very recognizably Christian community. Christianity saturated every part of people's lives, from their gardening and hunting, to many of their primary ways of socializing with one another. One could hear people saying Christian prayers almost whenever one chose to listen except the very dead of night, and sometimes even then. Moreover, people were in Church regularly, always on Saturday, Sunday and Wednesday, but often on other days as well. And Urapmin Christian ritual life was not in most cases terribly exotic or heavily syncretized. It was, rather, very firmly in the tradition of many Pentecostal and charismatic groups throughout the world. They had also become familiar with dispensational premillenisalist doctrines holding that Jesus could return at any moment and that bits of information they called "world news" might indicate that the last days had begun. In light of this doctrine, people were preoccupied with leading moral "Christian lives" so as to be ready for His 
coming. In this way too, their lives looked very similar to those of others who participate in one widely diffused tradition of contemporary Christianity.

\section{Cultural Theory and Cultural Change}

I could have told the story of the Urapmin revival by recounting a set of personal testimonies from Urapmin people reporting their profound experiences of the divine followed by individual conversion. I could also, as I have before, endeavored to "explain" their conversion in terms largely borrowed from sociological theory, asking what problems in pre-conversion Urapmin life might have led people to be ready for the revival when it came (Author 2004a). But rather than approach matters in these ways here, I have presented the conversions of the revival period as a force for broad cultural changes. For it was the fact of these changes that led me to take up issues of the link between conversion and cultural change that I am addressing here.

At the time of my fieldwork in the early 1990s, the very intense cultural changes that followed the onset of revival in Urapmin were of a kind that anthropologists thought to be highly unlikely and perhaps impossible. The almost immediate abandonment of traditional religion, the wholesale transformation of norms of gender segregation, including those reflected in the physical layout of people's primary living spaces, the thoroughgoing reworking of the ways people worked the landscape to produce food and

the patterns by which they consumed it - all of this could not happen in the space of less than one generation, much less in just a year, as the Urapmin claimed it had, or even in the 13 years between the advent of the revival and my arrival to begin fieldwork, by which time I can attest that the changes were fully in place and had already become 
routine. Anthropologists imagined that these kinds of changes might be possible in situations of conquest, or in modern conditions that many anthropologists in the early 1990s still did not regard as the main setting of their research, but such dramatic and rapid changes were not what any scholars in the discipline would expect for a remote population that had undergone almost no direct missionization and little practically effective transformation of their daily economic and political lives. This assumption is embedded in Robin Horton's (1971) famous work on conversion in Africa - which is, by my lights, one of the few really distinctive and influential theories of conversion to come out of anthropology. Horton argues that in Africa conversion to Christianity and Islam just pushes forward changes that political and economic dislocations have already rendered "'in the air' anyway" (p. 104). But Horton's approach fails to explain what happened in Urapmin. Before the revival, though the Urapmin had come to learn of the existence of ways of life significantly different from their own, Urapmin culture was not, one could argue, hugely "disturbed" - there had been little by way of major social upheavals that effected people's everyday lives very deeply. After the revival, as we have seen, many core aspects of that culture were radically different than they had been. This is not a kind of transformation anthropology as it stood in the early 1990s was primed to foresee or understand.

Why was this kind of dramatic cultural change so unexpected in anthropology in the early 1990s? Perhaps the key reason is that by that time anthropologists had a long habit of thinking about culture as something that tends to endure through time. In some respects, this followed from a division of labor put in place as the social and human sciences first began to achieve separate identities in the late 1800s. Sociology, as part of 
its charge to explore the transformations that had created and continue to shape modern life, was securely focused on social change. And even before the advent of sociology, the discipline of history had taken change in the historical development of the West as a core theme. In the wake of the prior claims of these disciplines, anthropology was left to study subjects like culture and tradition in places outside the heartlands of modernity, and non-modern cultures and traditions in this scheme of things were understood to be almost by definition largely unchanging (Fabian 1983).

As anthropologists developed expertise in studying non-modern cultures that they assumed persisted relatively unchanged through time, their theoretical traditions became adept at explaining this supposed quality of endurance. As the theologian Kathryn Tanner 1997: 23) puts it in her book Theories of Culture: A New Agenda for Theology, a work to which I will return, cultures, as anthropologists understood them, ...sustained themselves, simply by being repeated and by the force of habit and traditional authority that such repetition generated. They sustained themselves, in other words, mainly through unconscious processes of habitual repetition that conditioned the behaviors of every individual growing up in them (emph. in original).

One could enrich Tanner's account of how, in anthropological understanding, cultures sustained themselves - pointing, for example, to the fact that people are often heavily invested in the sense-making capacities of their cultures and so actively endeavor to perpetuate them, or noting the often very subtle ways in which people engaged in social interaction sanction those who deviate too far from the cultural scripts that shape its unfolding - but she is quite accurate in the basic thrust of her argument: culture, as 
anthropologists tended to conceive it throughout much of the history of their discipline, has been a phenomenon built to persist through time.

I have argued at length elsewhere that the anthropological assumption of and interest in cultural endurance is one of the more subtle, intellectually substantial reasons that anthropologists for a long time shied away from studying the cultures of Christians, and especially those of recent converts (Author 2007). I would add that I also think the anthropological concern with cultural continuity is the reason that, as Henri Gooren (2014: 85) puts it, “anthropologists have consistently struggled to come to terms with religious conversion" more generally. For our purposes, what is most important to recognize is that the notion that cultures tend to persist through time is the key reason that experiences of dramatic cultural change of the kind that have been so important in recent Urapmin history have not been something anthropology has expected to encounter or has prepared itself well to deal with.

As a PhD student returned from fieldwork in Urapmin in 1993, I faced the task of working against this disciplinary tradition to find a way to explore the contemporary lives and recent history of the people I studied without ignoring the major changes that were crucial to their own experience. As luck would have it, I was not alone in this. At this time, a number of other anthropologists had returned from fieldwork with recently converted Christians whose lives were also marked by extensive cultural changes (e.g. Meyer 1998, Engelke 2004, Eriksen 2008). Quickly, our various approaches to reckoning with the interrelation between conversion and cultural change made what came to be known as issues of cultural continuity and discontinuity core concerns of the developing anthropology of Christianity (Lampe 2010, McDougal 2009). What I want to 
do in the remainder of this article is consider some of what anthropologists of Christianity who are open to the possibility of radical transformation have learned about the connections between Christian conversion and cultural change.

Before I turn to detailing some key anthropological findings, however, I should pause to note one change in the general anthropological theorization of culture that provides crucial background for the discussion to come. Tanner (1997) makes the point I quoted above about the traditional anthropological assumption that cultures are enduring in the course of developing an argument that holds that in what she called the postmodern era of the late 1980s and 1990s anthropologists dropped this understanding of culture along with other related claims that cultural elements are widely and consensually shared by all members of a society and are all coherently related to one another. In place of this “modern" picture, Tanner (1997: 51) follows some postmodern anthropologists in sketching a new one in which social life is marked by constant argument and struggle between people over the meaning of virtually all important aspects of their lives. In the view of these scholars, cultural "change is no secondary matter" and instead "the constant possibility of change" is "the baseline against which stable, established cultural forms are measured...." Tanner's reporting is accurate here; many anthropologists did subscribe to such postmodern models of culture during the 1990s. And today, quite a few anthropologists do not imagine that they have much to do with the study of culture at all - preferring to think of themselves as studying individual experiences or the varying perspectives of people situated within the diverse groups that make up any social formation. The overwhelming emphasis on combative struggles over meaning that colors Tanner's own version of cultural theory now looks a bit faded and of its moment. Yet 
even as the model of social life as unending competitive strife has largely retreated from the scene, many anthropologists have continued to assume that for various reasons social life is subject to constant change. Strong models of culture as a force in shaping social life, much less models of the kind that theoretically justify an image of cultures as phenomenon that tends to endure through time, are not as dominant in contemporary anthropology as they once were.

One might think that this shift in many anthropologists' thinking about culture would have fostered a newfound interest in cultural change, maybe even in conversion. But outside of the anthropology of Christianity, this has not been the case. Perhaps this should not surprise us. For if people's lives are constantly subject to change, then change itself appears as a simple fact of life, in need of little study or explanation. This assumption in place, what Tanner calls "postmodern" models of culture have been no friendlier to issues of radical cultural change than the "modern" ones they displaced. In light of this development, I think that when studying conversion it is most useful to work with what we might call stronger, more "modern looking" models of culture - ones that see cultures as having a real role in shaping people's lives and that assume that much of the time people do reproduce their cultures in ways Tanner's modernist anthropologists predicted they would. Such models at least make conversion and the cultural changes it brings about worthy of study, rather than rendering it as just one more twist of the kaleidoscope's predictably ever-changing pattern.

I am not going to argue for the validity of such a strong version of culture in what follows - if I did so, there would be no time to discuss specifically Christian cultural dynamics of change. Instead, I am just going to put one such strong model of culture to 
use, suggesting that we see how far it gets us in examining the link between Christianity and cultural change. The version of culture that I have in mind focuses in particular on the role of cultural values in organizing other cultural elements and in shaping the lives of those who hold them.

By values I mean people's representations of things and states of affairs to which they find themselves positively drawn and to which they feel they should rightly be drawn in this way. One can define values in this sense as things and states of affairs people not only desire, but that they find desirable - that they in a second order way think it is right to desire and, to add a social twist to this, that they are comfortable telling others they desire. Values, to put this another way, are the things people are actively trying to realize or produce as they go about their lives.

One further quality of values is that they arrange the world into hierarchies of more and less desirable elements. On the strong version of culture I am putting forward here, cultures not only provide the conceptual categories by which people perceive their worlds, but as importantly they rank all of those categories relative to one another, such that, for example, they go beyond simply defining some things as, say, hot and others as, say, cold, to also assert that hot things are more desirable than cold ones or vice-versa. In this way, the values of a culture rank its various elements in relation to one another and, this model holds, these hierarchies play a major role in shaping how people live their lives, since people are inclined as much as possible to realize or produce things and states of affairs they find more valuable and to avoid devoting their energies to those they find less so. One virtue of this value-based model of culture is that it allows for a clear definition of radical cultural change - in this view, we can say that such radical change 
has occurred when people's values change, either because new values replace old ones, or because the hierarchical relations between existing values are transformed. ${ }^{2}$ In what follows, I consider some ways Christian conversion can bring about such changes in values.

\section{Christianity, Values and Cultural Change}

I am going to develop my account of Christian conversion, values and cultural change by taking a closer look at the Urapmin experience and by placing it in the context of some general themes from the anthropology of Christianity. I have already said enough to demonstrate that their conversion resulted in major, rapid cultural changes. But how did the Urapmin embrace of Christianity bring this about, and to what extent do we find the patterns of change that marked Urapmin conversion evident in other places? My discussion in what follows addresses these questions.

Let me begin with an observation that should be obvious. In situations of conversion, Christianity always comes after another culture - it is never in cultural terms a place where people begin. More than this, as the French scholar Rémi Brague (2002: 54) provocatively notes, Christianity is in its essence a religion of "secondarity" - one that sees itself as coming after a prior religion with which it sustains a complex relation that falls far short of simple rejection. When one studies conversion in places where people have had little contact with Christianity before, one thing that stands out is that part of Christianity's appeal is this quality of secondarity and the way it leads Christianity to acknowledge that converts start from somewhere else. For the Urapmin and many other new converts, for example, Pauline concerns about the relationship of Christianity 
to Judaism have a reassuring ring, indicating as they do that Christians are expected to have a past with which they must deal (Author 2010). Moreover, many converts find it compelling that they are expected not simply to forget that past, but to think critically about how to relate to it. Courtney Handman (2015), who has worked with Lutheran and Charismatic converts in Papua New Guinea whose churches have schismed several times over the question of whether or not traditional cultural forms should play a role in Church practice, argues that this emphasis on critically evaluating the past leads to a more general understanding among Christians that cultural criticism is a necessary religious and moral practice. To become Christian, on her account, is to come to see oneself as having a past and a traditional culture to take a critical approach to determining which parts of that past and that culture remain valuable and which do not.

Generalizing Handman's point, we might say that Christian converts are by nature cultural critics in relation to their traditional worldviews. This critical attitude is one important engine of cultural change in the conversion process. Yet there is also a second, closely related aspect of Christianity that drives forward processes of cultural change and gives them a distinctive Christian shape. Tanner (1997: 97) is once again useful here. She argues that Christianity rarely attempts to constitute an entire culture or create a whole society in its own terms. As she puts it, "The majority view in Christianity for most of its history never favored efforts to make Christian social practices into the sort of group that modern anthropologists would think of as possessing its own way of life." Thus, she adds, Christians have often participated in the "educational, economic, familial...[and] political" institutions of the wider societies of which they have been a part (see also Brague 2002: 160-165). Yet in engaging these institutions from the wider 
society, Tanner argues, Christians do not always relate to them in a manner of straightforward acceptance. Instead they "trope" on them, giving them new Christian meanings or otherwise bringing them in line with Christian concerns (p. 116). Although the anthropologist Simon Coleman (2006: 3) does not engage with Tanner's work, he captures the spirit of her argument and ties it neatly to Handman's point about Christianity's critical tendencies and my own emphasis on values when he argues that at least some forms of Christianity (he focuses on Pentecostal and charismatic Christianity) exist as as "part cultures" designed to interact with other cultures with which they come into contact not by replacing them wholesale, but by coming into "tension" with their values.

The picture that emerges from the work of Handman, Coleman, Tanner and Brague is one of Christianity as a religion that often sets up what we might think of as duplex cultural formations. These are formations in which the traditional cultures of converts are not jettisoned entirely or even transformed beyond all recognition, but in which Christians are challenged to take an evaluative position with regard to those cultures, often negotiating between their new Christian values and those that are central to their indigenous ways of living. The dynamics of this duplex structure, along with the critical attitude on which they are based, are at the heart of the cultural changes conversion brings in its train. Without a sense of how these dynamics operate, we are unlikely to be able to adequately understand the role of such changes in conversion.

I can return to the Urapmin experience to illustrate the duplex dynamics of cultural change that conversion to Christianity sets in train. As the Urapmin have come to understand Christianity, they see its most important value - the state of affairs they feel 
it tells them they should most desire and work toward realizing - as individual salvation. One reaches this state, as they understand it, by participating in a very active Christian ritual life that helps one to avoid as much as possible having sinful feelings and committing sinful acts and that offers ways of recovering from sins committed with the help of God and the Holy Spirit. And crucially for my analysis here, while other people such as pastors can help a person work toward the valued state of salvation, ultimately each person has to achieve it for themselves. It is a personal, not a social state. The Urapmin thus adhere to the idea that, as one Baptist theologian has put it, "God deals directly with each particular human person" (Holmes 2012: 6).

The placement of such a high value on a particular state of individual persons is not characteristic of traditional Urapmin culture. In that scheme of things, it is the relationships between people that is most highly valued, and much of social life should be aimed at making sure those relationships are kept in desirable conditions marked by high involvement and reciprocal treatment. As a quick exemplification of what this value on relationships looks like in practice, I might mention that the Urapmin are one of those Papua New Guinea societies that helped give us the anthropological notion of the gift that has recently had a bit of uptake in some corners of theology. Most food Urapmin people eat will have been given to them by someone else, and in turn they will give much of the food they grow away to others. The Urapmin call eating one's own food "eating for nothing." Better to give your taro and sweet potatoes to others to eat, and to consume the taro and sweet potatoes others give you, for that way food not only nourishes the body, it also nourishes the social relations in which people's lives are embedded. Because food should be used to meet both of these goals, even husbands and wives have separate 
garden areas within a plot, so that the crops they provide each other can count as relationship-enhancing gifts. And as Urapmin people walk down the paths that connect their villages to one another and to their gardens, they are constantly reaching in their string bags to give a little of the crop they have harvested to those they meet, and they are similarly receiving crops from others. And as with food, so with many other things in Urapmin life such as bows and arrows and string bags - people much prefer to give away versions of these things they make themselves and to use versions given to them by others. All of this gift giving and receiving helps to realize the key value placed on the creation and maintenance of social relationships in Urapmin.

Even after their conversion, the value of relationships remains crucially important in Urapmin. It still organizes many social interactions. But Urapmin also recognize that this value does not sit perfectly comfortably with that placed on the salvation of the individual in their understanding of Christianity. Often, in ways I do not have time to present here, they find that their efforts to realize traditional relational goals end up leading them into sin (Author 2004a). It is around the conflict between these two values that much of their energy as Christian critics and many of their attempts to trope traditional elements into their Christian framework revolve. I want to offer two brief examples of ways in which this value conflict and the troping to which it leads evidence themselves in Urapmin life.

My first example comes from one of the most remarkable conversations I had during my fieldwork. One night, I came across Rom in his house reading his copy of the New Testament in the Papua New Guinea lingua franca "tok pisin" by the light of his kerosene lamp. Rom was, in my experience, one of the most intelligent and articulate 
people in the Urapmin community. When I happened by his house on the night in question, he was reading and studying Matthew 25, the parable of the ten bridesmaids, five of whom were wise and had enough oil for their lamps but would not share their oil with the five foolish ones who did not, who then missed out on the bridegroom's coming while they were off seeking fresh supplies.

Now, this parable is important for almost all Urapmin for its final line, about keeping watch because one does not know the day nor the hour of Jesus's return. This line plays a key role in the way the Urapmin live with their very intense dispensational premillennial hopefulness, for it both pushes them to keep the millennial possibility ever in mind and gives them pause when they hear rumors, which they often do, that someone has determined that the second coming is about to commence immediately. But for some reason I cannot now reconstruct, when I bumped into Rom studying this passage by himself that night, I did not assume I knew why he thought the parable was important. Instead, I asked him what it meant. He answered that "this story means that belief is a big thing. Everyone has to have it for themselves." "My wife," he continued, "cannot break off part of her belief and give it to me, I cannot break off part of mine and give it to her." "Each person," he repeated, "must have it for themselves."

Rom was working here at the mismatch between Christian Individualism and the traditional understanding in which it is relationships, not individual persons, that accrue value and either succeed or fail in moral terms. The tenor of our conversation that night indicated that Rom feel that as a Christian he needs to put personal belief and the effort toward individual salvation at the top of his hierarchy of concerns. But at the same time, his interest in this parable and his interpretation of it suggest that he worries in a critical 
fashion about finding a way to allow traditional relational values, which lead people to "break off" parts of important things all the time to give to others, to have an important place in his life as well.

This struggle between individual and relational values is nowhere more dramatically displayed in Urapmin life than in my second example, one that takes up the Urapmin approach to the one traditional form of ritual they have not been able completely to do without. This is a healing ritual in which participants sacrifice a pig to a nature spirit in order to enjoin the spirit to stop afflicting a person with illness. In traditional Urapmin understanding, nature spirits that existed before human beings were created are the original owners of all elements of the natural landscape. These spirits generally allowed the Urapmin to use the resources they owned by hunting in their forests, making gardens on their land, eating the animals some of them looked after. But the spirits also put taboos in place to ensure that the Urapmin did not disturb them as they went about their subsistence work. In particular, people were not to talk loudly or laugh when they were using the spirits' resources. When people violated these taboos, the spirits made them sick. As far as Urapmin are concerned, all illnesses of any duration were in the past and, as we will see, still are caused by these spirits as punishments for violations of their taboos.

In a pattern of Christian critical evaluation of traditional cultural elements that is very common in cases of Pentecostal and charismatic conversion, the Urapmin still believe these spirits exist, but they have come to understand them in wholly negative terms, defining them as demons who exist only to cause disvalued states of sickness (Meyer 1999, Author 2004b). As I noted earlier when discussing the notion of free time, 
Urapmin now say that God made and owns the entire landscape and he wants the Urapmin to use it for their own productive purposes without regard for any taboos the nature spirits put in place in the past. Sickness is still caused by these spirits, but when one becomes sick one prays to God to banish the offending spirit and bind it in hell, where it can do no more harm. If an illness persists, members of their congregation can lay hands on the afflicted person in healing prayer, or the afflicted person can go to a new kind of healer known as a "Spirit Woman" who is adept at entreating the Holy Spirit to aid in the process of defeating offending nature spirits. The vast majority of illnesses are handled in these Christian ways.

There is, however, one further element of traditional Urapmin understandings of the nature spirits as sources of illness that has proved difficult to manage in the new Christian terms. Nature spirits are able to make adults sick, but they cannot kill them. All adult deaths are due to sorcery. But nature spirits can kill children. This means that people are deeply concerned when prayers and other Christian healing rites fail to cure a sick child. It is in this situation that they turn to a version of a traditional sacrificial ritual in which the sick child holds a rope tied to the foreleg of a pig that is shot during a ceremony in which the offending spirit is asked to take the smell of the cooked meat and leave the child alone.

This resort to a traditional-looking rite by a group of people who otherwise shun all engagement with their ritual past is as striking to the Urapmin as it is to me as an anthropologist. Many Urapmin are, in fact, opposed to any resort to these sacrifices. They assert that Jesus is supposed to have been the last sacrifice and that therefore Christians have no business performing a rite like this. But the fear of losing a child is 
too great to allow its relatives to hold back from using to all means they have at their disposal to stop such a death from occurring, and so people still do sometimes carry out these sacrifices.

For the purposes of my discussion of conversion and cultural change as turning on a struggle between values, it is not simply the continued practice of the rite or the controversy that surrounds it that is most important. Instead, it is crucial to notice several ways in which the traditional form of the sacrifice is modified as it is brought into critical relationship with Urapmin Christianity. First, sacrifices are always understood as having been ordered by the Holy Spirit, who calls for them through the Spirit women healers I mentioned above. Secondly, the sacrifices are accompanied by Christian prayers that carefully bring them into a Christian framework. Here is an example of such a prayer in which these dynamics are in play:

[1] God, you! God. Holy God. I pray to you now. As you can see, the daughter of my younger sister and her husband has been sick. We family are gathered here.

[2] Please God, you have power. God you have strength. God you have glory. You are the God of mercy, the God of peacefulness. I am praying in your name. You must heal this daughter of mine.

[3] My child Kiki (the sick girl's father) and my younger sister, this couple's daughter, Jesus you appear to her. Come down to her and bring your heavenly, sharp knife and chop off the tails and the hands of the spirits. Send away the spirits of Alal [a place], spirits of Lalip [a place], spirits of the Wim tem cave, spirits of Delolbikma [a place], Spirits of Bantok [a place], and the bad animal spirits, like those of the Belulumin species of flying fox.

[4] Only you Jesus have power. Its like when people are sick, when they have a problem. That's what they said in James chapter 5 verses 13, 14 and 15. It said that 'if your friend has a heavy, like he has become sick, you must 
go see him and you must put him...the church leaders can come, like the pastor or deacon, Spirit women and men [there is one Spirit man in Urapmin]. You strong Christians should come and stay with your friend like that and pray for him and I will hear it. I will heal your friend who is sick. And if your friend sins, if he has become heavy with his sin, I will heal him, I will take back his life, or put back his life. I will heal him.' This is what you have said and so my child's child, Jesus you! You - we brothers and sisters are people but you are holy and clean - we pray to you.

[5] We say you will heal this child and so she has come and I am praying. And also, we will kill a good, small young piglet in order too...to kill it and then we must cook it. That's the way we can heal her with the piglet. She has brought it and we family want to kill it.

[6] Bad spirits, ghosts, hidden people, she [this can refer to the Holy Spirit, who is grammatically feminine, as well as to the Spirit woman] will throw them all out. She will throw out all the spirits.

[7] Jesus, you were a good lamb that died to bring our lives back to us. That's what you did and we too bring a young, child pig and kill it and do a ritual about this [the Tok Pisin word translated here as 'do our ritual' is 'singsing' - at least by way of connotation, it would refer to a traditional ritual since 'singsing' is rarely used to refer to Christian practice]. This is what we will do and so God you look at us. God send down only your strength. Its just meat, so we will kill it and eat it and so God send down only your strength and holiness and heal this child.

[8] Please, I have said this and God, you! God you are merciful, you are peaceful, you are happy and so I pray to you. Please look carefully at this child and heal her. Chop off the hands and feet of the poison snake spirit, the dog spirit, the cassowary spirit, the echidna spirit, whatever kind of spirit-like things, residents of the trees, any kind of man [a way of referring to spirits], any kind of man, snake spirits, any kind of man, send him away to his own house. You take him and step on him and crush him and, please, heal this child. 
[9] I send her to you Jesus, to your realm of life. Resident of Nazareth, she comes to your holy presence. Please appear and heal her.

[10] My child's child has been sick. I pray for her but I am a sinful man. Some have not come to see her, I have not, so holy God please appear and heal her of this. Jesus, only you can heal my child's family's daughter. We father's and mother's brother's are just men, so Jesus please you yourself [must do this]. Jesus, I send her to you. I have said enough and it is true [this is the formulaic conclusion used with most prayers]. ${ }^{3}$

I will not go through this prayer in detail, but will just point out that the references to the verses from James tropically define the entire event as a Christian healing ritual, a point reinforced when Jesus and God are entreated to remove the spirit from the sick child, and the pig itself is referred to as "just meat" that people will eat, indicating that the sacrifice itself lacks all efficacy. These statements work together to make the sacrifice a key instance in which Urapmin Christianity enters into critical dialogue with their tradition, and in which people represent Christianity as having the upper hand.

We can say more than this, however, if we look at one further change the Urapmin have made to the way they understand these sacrificial rites. Traditionally, these rituals constituted an exchange with a nature spirit, one in which people gave the spirit a pig in order to repair the relation between themselves and the spirit that had been damaged by their violation of spirit's taboo. Urapmin repair relations between estranged people with ritualized exchanges that represent formalized versions of the kinds of gift giving that realize the value of relationships in daily life. In their sacrificial rites, they did the same with spirits. Traditional sacrifice, then, was an important ritual expression of relational values. 
In Urapmin Christianized sacrifices, by contrast, as in their other Christian healing rites, the emphasis, as evidenced in the prayer I just presented, is not on the repair of relations with spirits, but on the banishment and violent destruction of the spirits. The rite now heals not by repairing relations between a person and a spirit, but by leaving the person free of any relationship to the spirit at all. When the pastor in the prayer I have just presented proclaims that the piglet is "just meat, so we will kill it and eat it," it is as if he is underlining this point, not only asserting that the sacrifice has no efficacy of its own, since all power belongs to God, but even suggesting that no gift will be given to the spirit at all, since the emphasis is squarely on the pig as food for the human participants in the rite. In this way, the sacrificial rite is transformed from an expression of relational values to a key representation of individualist ones. It is all about creating a valuable state in the sick person, and it wholly disavows the prior relation between the person and the spirit to achieve this goal. Thus it is Christian values, and not just Christian ideas or beliefs, that this subtly revised form of pig sacrifice represents as ranking more highly than traditional ones. In their contemporary form, then, Urapmin pig sacrifices are an excellent example of duplex cultural processes at work.

\section{Conclusion}

I recognize that there has been something of a disjunction between the way in which I presented the Urapmin experience of conversion at the outset of this article and the way I have discussed it just now, toward the end. Putting the contrast most starkly, when first introducing the Urapmin I focused on the radical cultural changes they experienced during the early years of their conversion: the destruction of the physical 
expressions of their traditional religion, the abrogation of taboos, and the upturning of traditional gender arrangements. In this version, Christianity quickly and thoroughly ran the table in cultural terms, leaving little of religious or social importance unchanged. Urapmin indeed see matters largely this way, and they are very confident in their sense of themselves as Christian. In my later discussion of the Urapmin, by contrast, I have introduced what looks like a more complicated picture, one in which nature spirits still play an important role in Urapmin life, people still sometimes practice traditional-looking sacrifices, and on at the level of cultural organization Christian values have constantly to negotiate their relation to traditional ones that do not fully tally with them. This picture, too, is consonant with Urapmin experience, and in ways I have not been able to detail here, they explicitly express its primary features most consistently in their regular claims that they find it difficult to avoid falling into what in Christian terms they understand as $\sin$ (see Author 2004a). In conclusion, I want to suggest that if we can develop a way to understand how both pictures represent aspects of the truth of the Urapmin experience, we will have learned something about one pattern by which conversion can create cultural change.

Drawing on arguments I have already made, I would suggest that they key to understanding the co-existence of these two faces of Urapmin life is what I earlier called the duplex, or secondary and critical qualities of Christianity as a religion. To struggle in the way the Urapmin have with the problem of negotiating between their firm commitment to Christian values and the continued existence of traditional values and other features of their lives that they do not recognize as wholly Christian, or that they feel do not help them to realize their core Christian value of individual salvation, is a very 
recognizable way of being a Christian in other places as well. This is clearly true among recent converts, but it is not absent in places where Christianity has long been a dominant faith. For even in places where Christianity has traditionally been the primary religion, the relations of Christians to what they often call "the world" are seldom fully settled. I think Tanner sets up this point with her notion of Christianity never constituting a social world wholly on its own - it always leaves a world beyond itself to be reckoned with. And in hindsight, the briefly prominent modern Western construal of the relationship of Christianity to the social world as one of complete harmony or identity that Richard Niebuhr (2001: xlv) defined the "Christ of culture" looks more like an outlier than the norm.

Less harmonious relations between Christianity and the world do not in every case turn on the same issues. Even within the literature anthropology has thus far produced on Christianity, still relatively small compared to many other disciplines, the fault-lines of struggle I have identified among the Urapmin, between an individualist engagement with Christianity and a traditional valuation of relationships, is not one scholars have always found replicated elsewhere (see Bialecki and Daswani 2015 and Author 2015 for debates over the prevalence of this pattern). In other places, anthropologists and those with whom they engage have found Christians more eager to work on conflicts around models of political action (Marshall 2009, O’Neill 2010), economic life (Comaroff and Comaroff 1991), gender relations (Brusco 1995, Eriksen 2008, Mariz and Machado 1997, Author 2012), the value of the material world (Engelke 2007, Webster 2013), and the propriety of traditional cultural expressions (Handman 2015). This list is already long and it could be longer, but in the present context its length 
is not the point. Our focus is rather on the kind of cultural formation all of these cases illustrate - a cultural formation in which people experience their religious lives as necessitating a constant critical engagement with many other parts of their culture. If, to answer my initial question, to relate to one's culture in this critical way is part of what it means to become Christian, then Christian conversion will always entail cultural change - not only initially, when a convert at least minimally takes on a new religious identity, but in an ongoing sense as well, since Christianity's duplex character makes efforts at cultural evaluation and transformation a core aspect of Christian life.

Perhaps this conclusion appears obvious to readers so long engaged with understanding the relationship between Christian conversion and cultural change. I light of this possibility, I just want to take a final moment to point out one common way of understanding the relationship between Christianity and what we might call indigenous cultures that the model I have presented here puts to one side. This anthropological construal of Christianity as in its nature a duplex cultural formation does not suggest that it is useful to look at post-conversion cultural change as giving birth to forms of syncretism or cultural mixing, at least as we usually imagine these phenomena. I realize that syncretism is a complex term with a range of meanings in different disciplinary contexts (Author 2011). But it often connotes a sense of incomplete religious adherence and it is also in many uses an unstructured notion that suggests little about how the different elements that go into a syncretic formation relate to one another. Put more directly, it has little room for the kinds of conflicted value relations between cultural elements that have preoccupied me here. The Urapmin do not define their Christianity as mixed in any way, for they see themselves as trying to live lives in which its values are 
paramount. This is why they can tell the first story about themselves, the one of rapid and complete conversion, without evidencing any doubt. They are secure that in value terms their Christian project comes first for them, and to analyze their conversion in any way that does not do justice to this fact, say by describing their current cultural formation as syncretic, would, at least in anthropological terms, be a mistake. But to ignore their ongoing critical struggles to situate their Christianity in relation to their other, traditional values would be to misunderstand their situation just as badly. The burden of my argument has been that these kinds of struggle are a constitutive part of Christian life as anthropologists observe it, not a sign of a failure to live it correctly or completely. For anthropologists interested in the ways in which human beings can live flourishing lives, to study Christianity is to commit to exploring the cultural dynamics of duplex formations in which struggles like those of the Urapmin drive life forward and render meaningful the worlds that Christian people inhabit. 


\section{Notes}

\footnotetext{
${ }^{1}$ I have discussed the Urapmin case in great detail in Author 2004a. I will not cite this book repeatedly here. Except when I cite other of my own ethnographic works, the fullest account of the points I am making about the Urapmin are drawn from this work.

${ }^{2}$ I have developed the model of culture and values I deploy here in a number of places. Author 2004a contains a full, early discussion while Author 2007b is highly relevant to my discussion here. Author 2015 makes some further arguments that also bear on this paper.

${ }^{3}$ This prayer is reproduced from Author 2009.
}

\section{References}

Author

2003 What is a Christian? Notes Toward and Anthropology of Christianity. Religion 33(3):191-199.

2004a Becoming Sinners: Christianity and Moral Torment in a Papua New Guinea Society. Berkeley: University of California Press.

2004b The Globalization of Pentecostal and Charismatic Christianity. Annual Review of Anthropology 33:117-143.

2007a Continuity Thinking and the Problem of Christian Culture: Belief, Time and the Anthropology of Christianity. Current Anthropology 48(1):5-38.

2007b Between Reproduction and Freedom: Morality, Value, and Radical Cultural Change. Ethnos 72(3):293-314.

2009 Conversion, Hierarchy, and Cultural Change: Value and Syncretism in the Globalization of Pentecostal and charismatic Christianity. In Hierarchy: Persistence and Transformation in Social Formations. K. M. Rio and O. H. Smedal, eds. Pp. 65-88. New York: Berghahn.

2010 Anthropology, Pentecostalism, and the New Paul: Conversion, Event, and Social Transformation. South Atlantic Quarterly 109(4).

2011 Crypto-Religion and the Study of Cultural Mixtures: Anthropology, Value, and the Nature of Syncretism. Journal of the American Academy of Religion 79(2):408-424.

2012 Spirit Women, Church Women, and Passenger Women: Christianity, Gender, and Cultural Change in Melanesia. Archives De Sciences Sociales Des Religions 157:113133. 
2014 The Anthropology of Christianity: Unity, Diversity, New Directions (An Introduction to Supplement 10). Current Anthropology 55(S10):S157-S171.

2015 Dumont's Hierarchical Dynamism: Christianity and Individualism Revisited. Hau: Journal of Ethnographic Theory 5(1):173-195.

Bialecki, Jon, and Girish Daswani

2015 What is an Individual: The View From Christianity. Hau: Journal of Ethnographic Theory 5(1):271-294.

Brague, Rémi

2002 Eccentric Culture: A Theory of Western Civilization. South Bend: St. Augustine's Press. Brusco, Elizabeth E.

1995 The Reformation of Machismo: Evangelical Conversion and Gender in Colombia. Austin: University of Texas Press.

Cannell, Fenella

2006 Introduction: The Anthropology of Christianity. In The Anthropology of Christianity. Vol. Duke. F. Cannell, ed. Pp. 1-50: Durham.

Coleman, Simon

2006 Studying "Global" Pentecostalism: Tensions, Representations and Opportunities. PentecoStudies 5(1):1-17.

Comaroff, Jean, and John Comaroff

1991 Of Revelation and Revolution: Christianity, Colonialism, and Consciousness in South Africa. (Volume One). Chicago: University of Chicago Press.

Engelke, Matthew

2004 Discontinuity and the Discourse of Conversion. Journal of Religion in Africa 34(1-2):82109.

2007 A Problem of Presence: Beyond Scripture in an African Church. Berkeley: University of California Press.

Eriksen, Annelin

2008 Gender, Christianity and Change in Vanuatu: An Analysis of Social Movements in North Ambrym. Aldershot: Ashgate.

Fabian, Johannes

1983 Time and the Other: How Anthropology Makes its Object. New York: Columbia University Press.

Gooren, Henri

2014 Anthropology of Religious Conversion. In The Oxford Handbook of Religious Conversion. L. R. Rambo and C. F. Farhadian, eds. Pp. 84-116. Oxford.

Handman, Courtney

2015 Critical Christianity: Translation and Denominational Conflict in Papua New Guinea.

Berkeley: University of California Press.

Holmes, Stephen R.

2012 Baptist Theology. London: Continuum.

Horton, Robin

1971 African Conversion. Africa 41(2):85-108.

Lampe, Frederick 
2010 The Anthropology of Christianity: Context, Contestation, Rupture, and Continuity. Reviews in Anthropology 39(1):66-88.

Mariz, Cecília Loreto, and María das Dores Campos Machado

1997 Pentecostalism and Women in Brazil. In Power, Politics, and Pentecostals in Latin America. E. L. Cleary and H. W. Stewart-Gambino, eds. Pp. 41-54. Boulder: Westview.

Marshall, Ruth

2009 Political Spiritualities: The Pentecostal Revolution in Nigeria. Chicago: University of Chicago Press.

McDougall, Debra

2009 Rethinking Christianity and Anthropology: A Review Article. Anthrpological Forum 19(2):185-194.

Meyer, Birgit

1998 'Make a Complete Break with the Past': Memory and Postcolonial Modernity in Ghanaian Pentecostal Discourse. In Memory and the Postcolony: African Anthropology and the Critique of Power. R. Werbner, ed. Pp. 182-208. London: Zed Books.

1999 Translating the Devil: Religion and Modernity among the Ewe in Ghana. Trenton: Africa World Press.

Niebuhr, H. Richard

2001 [1951] Christ and Culture. San Francisco: HarperSanFrancisco.

O'Neill, Kevin Lewis

2010 City of God: Christian Citizenship in Postwar Guatemala. Berkeley: University of California Press.

Tanner, Kathryn

1997 Theories of Culture: A New Agenda for Theology. Minneapolis: Fortress Press.

Webster, Joseph

2013 The Anthropology of Protestantism: Faith and Crisis among Scottish Fishermen. New York: Palgrave. 